Bài báo khoa học

\title{
Úng dụng mô hình MIKE NAM, MIKE 11 HD tính toán tài nguyên nước mặt lưu vực sông Cửu Long
}

\author{
Nguyễn Ngọc Hà ${ }^{*}$, Nguyễn Mạnh Trình ${ }^{1}$, Hoàng Thị Nguyệt Minh² \\ ${ }^{1}$ Trung tâm Quy hoạch và Điều tra Tài nguyên Nước Quốc gia, Bộ Tài Nguyên và Môi \\ trường, 93/95 Vũ Xuân Thiều, Sài Đồng, Long Biên, Hà Nội; ha_tnn@yahoo.com; \\ manhtrinh021@yahoo.com.vn \\ ${ }^{2}$ Khoa Tài nguyên nước, Trường Đại học Tài nguyên và Môi trường Hà Nội; \\ htnminh.tnn@hunre.edu.vn
}

*Tác giả liên hệ: ha_tnn@yahoo.com; Tel.: +84-989668363

Ban Biên tập nhận bài: 12/7/2021; Ngày phản biện xong: 24/8/2021; Ngày đăng bài: $25 / 11 / 2021$

Tóm tắt: Lưu vực sông Cửu Long là phần hạ nguồn của lưu vực sông Mê Công trên địa phận Việt Nam thuộc địa bàn 13 tỉnh/thành vùng Nam bộ có nhiều tiềm năng phát triển kinh tế cả về nông nghiệp, công nghiệp, thủy sản và du lịch sinh thái. Mặc dù có hệ thống kênh rạch dày đặc nhưng nguồn nước của lưu vực sông Cửu Long lại phụ thuộc rất lớn vào lượng nước từ thượng nguồn. Để phục vụ quản lý, quy hoạch và phát triển bền vững lưu vực thì việc đánh giá được tài nguyên nước mưa, nước mặt đến từ thượng nguồn và sinh ra trên lưu vực sông Cửu Long là vô cùng quan trọng. Nghiên cứu này đã tổng hợp, phân tích tài liệu liên quan đến nguồn nước mặt, kết hợp với sử dụng công cụ mô hình toán thủy văn MIKENAM, thủy lực MIKE 11 HD để tính toán các đặc trưng và đưa ra bức tranh tương đối rõ nét về hiện trạng tài nguyên nước mưa, nước mặt lưu vực sông Cửu Long. Kết quả cho thấy tổng tài nguyên nước mưa toàn lưu vực là 68,4 tỷ $\mathrm{m}^{3}$, tài nguyên nước mặt là 471 tỷ $\mathrm{m}^{3}$ trong đó, sinh ra từ mưa nội vùng lưu vực sông Cửu Long là 30 tỷ $\mathrm{m}^{3}$ và từ nước ngoài (vùng thượng nguồn) qua hệ thống sông chính và chảy tràn biên giới là 441 tỷ m³ .

Từ khóa: Tài nguyên nước mặt; Lưu vực sông Cửu Long; MIKE-NAM; MIKE 11 HD.

\section{Mở đầu}

Trên thế giới hiện nay rất nhiều phương pháp tiếp cận để đánh giá tài nguyên nước mặt đối với các lưu vực sông. Trong đó, nhờ sự phát triển vượt bậc của công nghệ thông tin, phương pháp mô hình toán mô phỏng được ứng dụng rất rộng rãi cho kết quả tin cậy.

Năm 2014, JICA (WUP-JICA) [1] đã sử dụng mô hình Mike NAM và Mike 11 để tính toán dòng chảy cho vùng đồng bằng ngập lũ Campuchia từ hạ lưu Kratie đến biên giới Việt Nam. Kết quả đã chỉ ra được các tỷ lệ phân bố dòng chảy trong sông cũng như trên các khu vực ngập lũ của đồng bằng châu thổ Mê Công ở địa phận Campuchia. Tuy nhiên nghiên cứu này chỉ quan tâm chính đối với dòng chảy phía Campuchia, sự phân hóa theo mùa (lũ, cạn) mà chưa có sự đánh giá tổng thể về tài nguyên nước cả năm cũng như trên địa phận Việt Nam.

Năm 2016, trong dự án Nghiên cứu đánh giá tác động của các công trình trên thủy điện dòng chính Mê Công đã sử dụng kết hợp các mô hình SWAT-MIKE 11-MIKE21-MIKE BASIN để mô phỏng tính toán toàn bộ quá trình thủy văn lưu vực và thủy lực, sinh thái của dòng chính sông Mê Công [2]. Đây là nghiên cứu tổng thể nhất của lưu vực sông Mê Công 
trong nhiều lĩnh vực chịu tác động của các yếu tố thủy văn sinh thái sông Mê Công. Nghiên cứu này cũng chỉ tập trung so sánh sự thay đổi của các yếu tố thủy văn, sinh thái so với điều kiện năm thủy văn nền do đó cũng chưa có sự tính toán cho toàn bộ chuỗi dòng chảy nhiều năm.

Trong những năm qua, tại Việt Nam cũng đã có nhiều công trình nghiên cứu về dòng chảy lũ [3], lũ-kiệt [4], xâm nhập mặn [5] của vùng ĐBSCL, trong đó hệ thống các mô hình toán chủ yếu được sử dụng trong tính toán là MIKE NAM, MIKE 11, MIKE 21 [4]. Các mô hình trên được áp dụng tương đối nhiều trong nghiên cứu tính toán, dự báo ở các đơn vị phía Nam như Viện Khoa học thủy lợi miền Nam, Viện Quy hoạch thủy lợi miền Nam, Đài khí tượng thủy văn Nam Bộ...Năm 2016, Bộ Xây Dựng cũng đã sử dụng mô hình Mike 11 để lập Báo cáo chính Quy hoạch cấp nước vùng Đồng bằng sông Cửu long đến năm 2030 tầm nhìn đến năm 2050 [7].

Gần đây nhất, năm 2021, Bộ Kế hoạch và Đầu tư đã lập Báo cáo Quy hoạch vùng Đồng bằng sông Cửu Long thời kỳ 2021-2030, định hướng đến năm 2050 trong đó cũng sử dụng mô hình Mike NAM và Mike 11 để tính toán các kịch bản và phân vùng sinh thái cho vùng ĐBSCL [8]. Đồng bằng sông Cửu Long (ĐBSCL) nằm ở khu vực hạ lưu sông Mê Công có lượng mưa năm không lớn dao động từ 1200-2400 mm/năm, trung bình đạt khoảng 1733 $\mathrm{mm} / \mathrm{năm}$. Theo không gian lượng mưa thấp ở dọc vùng sông Tiền và tăng dần về phía Bắc và phía Nam, cao nhất là khu vực ven biển từ Cà Mau đến Kiên Giang. Sự phân bố của lượng mưa không đều, đồng thời dòng chảy phụ thuộc lượng nước từ thượng lưu gây bất lợi cho khai thác sử dụng nước, đặc biệt là trong mùa khô.

Mặc dù Đồng bằng sông Cửu Long được đánh giá tài nguyên nước phong phú [8-9], trung bình nhiều năm khoảng 500 tỷ $\mathrm{m}^{3}$ chiếm $57 \%$ tổng lượng của cả nước, tuy nhiên, có đến 475 tỷ $\mathrm{m}^{3}$ từ nước ngoài, dòng chảy nội sinh chỉ khoảng 25 tỷ $\mathrm{m}^{3}$ ( $5 \%$ tổng lượng dòng chảy). Nằm ở cuối hạ nguồn lưu vực sông Mê Công, lưu vực sông Cửu Long (LVSCL) chịu ảnh hưởng mạnh mẽ vào quá trình khai thác và sử dụng nước của tất cả các quốc gia thượng lưu, đặc biệt là tác động của hệ thống thủy điện cả trên dòng chính và dòng nhánh sông Mê Công $[2,9]$. Tác động của hệ thống thủy điện đến LVSCL được nhận biết gồm: (i) làm biến đổi chế độ thủy văn, trong đó có xu thế giảm lũ trung bình và nhỏ, tăng lũ lớn; (ii) giảm lượng phù sa; (iii) giảm nguồn lợi thủy sản và tính đa dạng sinh học; (iv) làm gia tăng tác động của BĐKH lên vùng châu thồ; và (v) gia tăng các vấn đề về quản lý tài nguyên nước và lưu vực sông...

Như vậy, trên LVSCL đã có khá nhiều các nghiên cứu sử dụng các mô hình toán thủy văn, thủy lực để phục vụ cho các lĩnh vực chuyên môn. Trong đó, các mô hình toán Mike NAM, Mike 11 đã cho thấy khả năng áp dụng tốt đối với lưu vực sông Cửu Long, cho kết quả tin cậy. Hầu hết các ứng dụng này tập trung đáp ứng nhu cầu quản lý, khai thác và sử dụng nước của từng ngành riêng lẻ (ngành xây dựng, giao thông...), theo thời kỳ (mùa lũ, mùa cạn) mà chưa xem xét đánh giá toàn diện tiềm năng nguồn nước mưa, nước nội sinh và nước mặt sông chính trong cả năm-đầu vào cơ bản cho bài toán lập quy hoạch tài nguyên nước. Do đó, đánh giá được tiềm năng tài nguyên nước và sự phân bố, diễn biến của nó là cơ sở vững chắc phục vụ cho quy hoạch tài nguyên nước LVSCL, cũng như các ngành kinh tế khác, thích ứng và chống chịu với biến đổi khí hậu nhằm phát triển bền vững.

\section{Phương pháp nghiên cứu}

\subsection{Giới thiệu khu vục nghiên cúu}

Sông Mê Công dài 4.200 km, chảy qua 6 nước là Trung Quốc, Myanmar, Thái Lan, Lào, Campuchia và Việt Nam, có diện tích lưu vực $795.000 \mathrm{~km}^{2}$, trong đó vùng LVSCL với tổng diện tích $39.400 \mathrm{~km}^{2}$ [10]. LVSCL phía bắc giáp LVS Đồng Nai, phía Tây giáp nước bạn Lào, phía Đông và phía Tây là Biển. Toàn bộ ĐBSCL bao gồm 13 tỉnh/thành gồm Long An, 
Tiền Giang, Đồng Tháp, Vĩnh Long, Trà Vinh, Hậu Giang, Sóc Trăng, Bến Tre, An Giang, Kiên Giang, Bạc Liêu, Cà Mau và TP. Cần Thơ.

ĐBSCL có vị trí quan trọng trong phát triển kinh tế-xã hội Quốc gia (Hình 1). Với tiềm năng nông nghiệp và thuỷ sản to lớn, hàng năm đóng góp khoảng $53 \%$ tổng sản lượng lương thực, $65 \%$ sản lượng thuỷ sản nuôi trồng và $70 \%$ trái cây của cả nước [8]. Tuy nhiên, vùng đồng bằng hạ lưu của một lưu vực sông lớn, đồng thời nằm ở vùng biển với hai chế độ thuỷ triều khác nhau đã tạo nền hệ thống kênh rạch dày đặc có chế độ thủy văn thủy lực phức tạp. ĐBSCL luôn phải đối mặt với các thiên tai, bao gồm (a) lũ và ngập lụt ở vùng đầu nguồn đặc biệt vùng Tứ giác Long Xuyên và Đồng Tháp Mười; (b) xâm nhập mặn ở toàn bộ vùng ven biển từ Long An đến Hà Tiên; (c) đất phèn và sự lan truyền nước chua ở những vùng trũng thấp; (d) thiếu nước ngọt; (đ) xói lở bờ sông-bờ biển; (e) cháy rừng và (g) ô nhiễm nguồn nước [14].

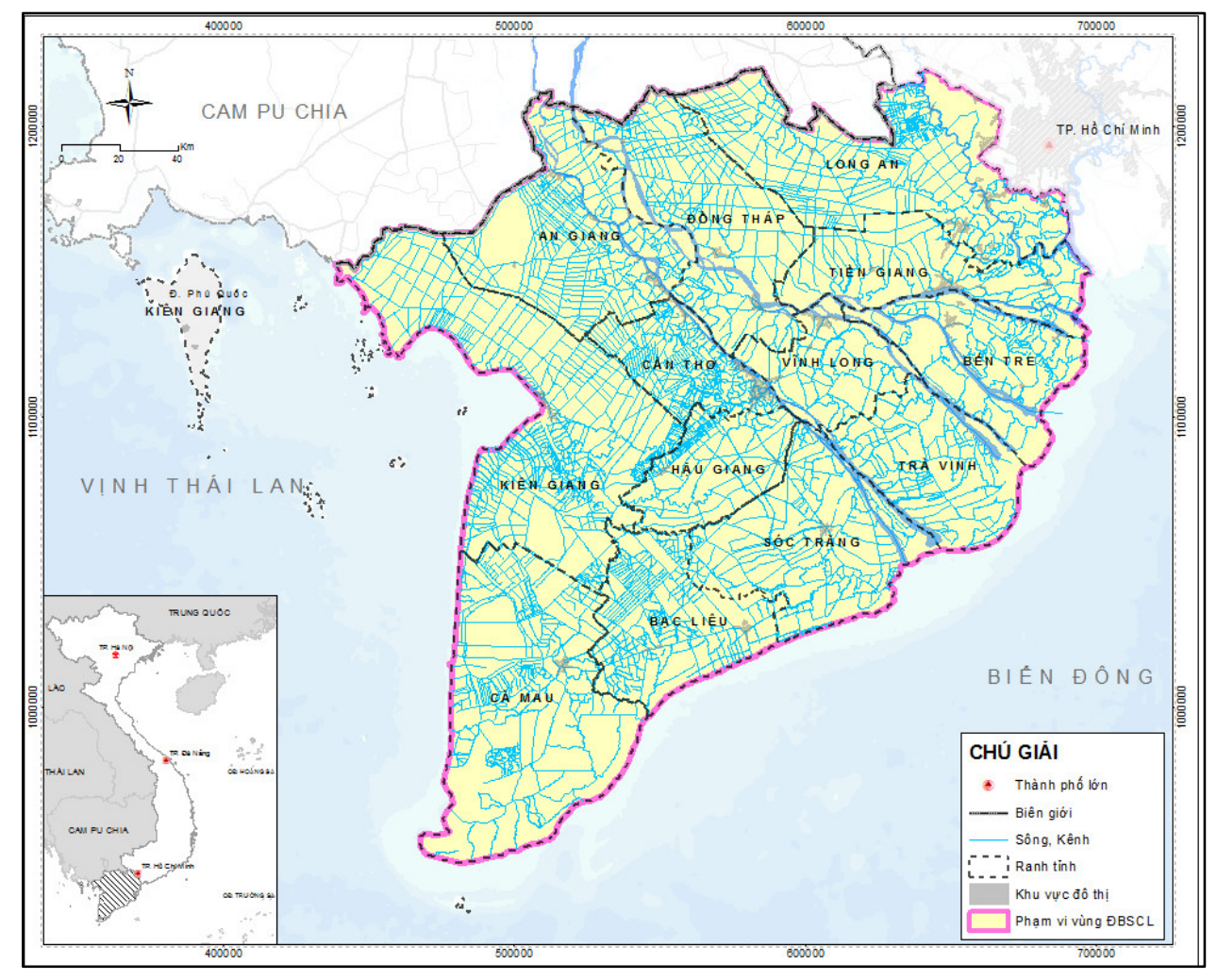

Hình 1. Vị trí đồng bằng lưu vực sông Cửu Long.

\subsection{Phưong pháp và nội dung nghiên cưu}

Trong nghiên cứu này sử dụng 3 phương pháp nghiên cứu chủ đạo bao gồm:

(1) Phương pháp tổng hợp, phân tích tài liệu, số liệu dựa trên các nguồn tài liệu [11], [12], số liệu hiện có $[8,13,14]$ liên quan đến nguồn nước mặt trên lưu vực bao gồm số liệu khí tượng, thủy văn, số liệu dân sinh kinh tế; các đề tài nghiên cứu [9], sách chuyên khảo [15-16] có liên quan đã thực hiện trong và ngoài Bộ Tài nguyên và Môi trường;

(2) Phương pháp mô hình toán, nghiên cứu sử dụng mô hình MIKE-NAM [17], MIKE $11[4,18]$ thiết lập và tính toán đặc trưng dòng chảy năm trung bình nhiều năm giai đoạn 1980-2019 cho các tiểu vùng và toàn bộ LVSCL;

(3) Phương pháp thành lập bản đồ được xây dựng trên cơ sở tích hợp mô hình thủy văn thủy lực và công cụ GIS [19] cũng được sử dụng để thể hiện một số kết quả nổi bật trong nghiên cứu này.

Sơ đồ khối nghiên cứu tính toán tài nguyên nước mặt LVS Cửu Long được trình bày trong Hình 2. 


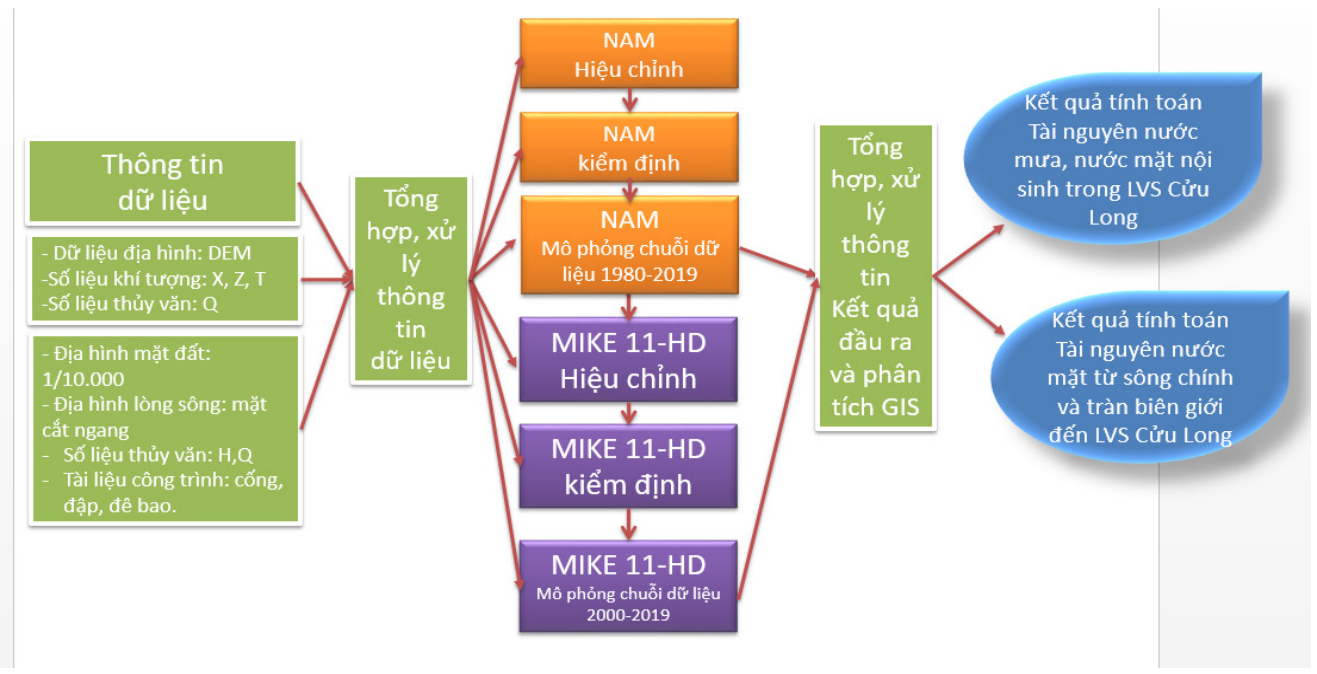

Hình 2. Sơ đồ khối nghiên cứu tính toán tài nguyên nước mặt LVS Cửu Long.

Trên cơ sở phân tích, đánh giá điều kiện tự nhiên, khí tượng thủy văn, kinh tế-xã hội và phương hướng phát triển của vùng, nghiên cứu thực hiện các nội dung sau: (1) Đánh giá tài nguyên nước mưa, các đặc trưng mưa và chế độ mưa trên LVSCL; (2) Thiết lập mô hình thủy văn MIKE NAM kết hợp với mô hình thủy lực MIKE 11HD để xác định tổng tiềm năng nguồn nước đến vùng ĐBSCL và các tiểu vùng từ các số liệu quan trắc mưa, bốc hơi tại các trạm khí tượng, khí hậu trên lưu vực trong điều kiện hạn chế về số liệu thủy văn. Đây là các kết quả chủ yếu nhằm mục đích xác định tiềm năng khai thác và phân bổ nguồn nước cho LVSCL. Chi tiết các bước thiết lập như sau:

\subsubsection{Thiết lập mô hình thủy văn Mike NAM}

a. Phân chia các tiểu lưu vực

Căn cứ vào bản đồ địa hình, hệ thống sông, kênh và sơ đồ mạng thủy lực hiện có, phân chia các lưu vực như sau: Toàn bộ vùng đồng bằng từ Kratie đến hết vùng ĐBSCL được chia thành 149 tiểu lưu vực (Hình 3) trong đó phía Camphuchia là 17 tiểu lưu vực, LVS Đồng Nai là 11 tiểu lưu vực, vùng ĐBSCL là 120 tiểu lưu vực. Kết quả phân chia các lưu vực là cơ sở tính toán tài nguyên nước mưa và nước mặt nội sinh từ mưa của các tiểu lưu vực.

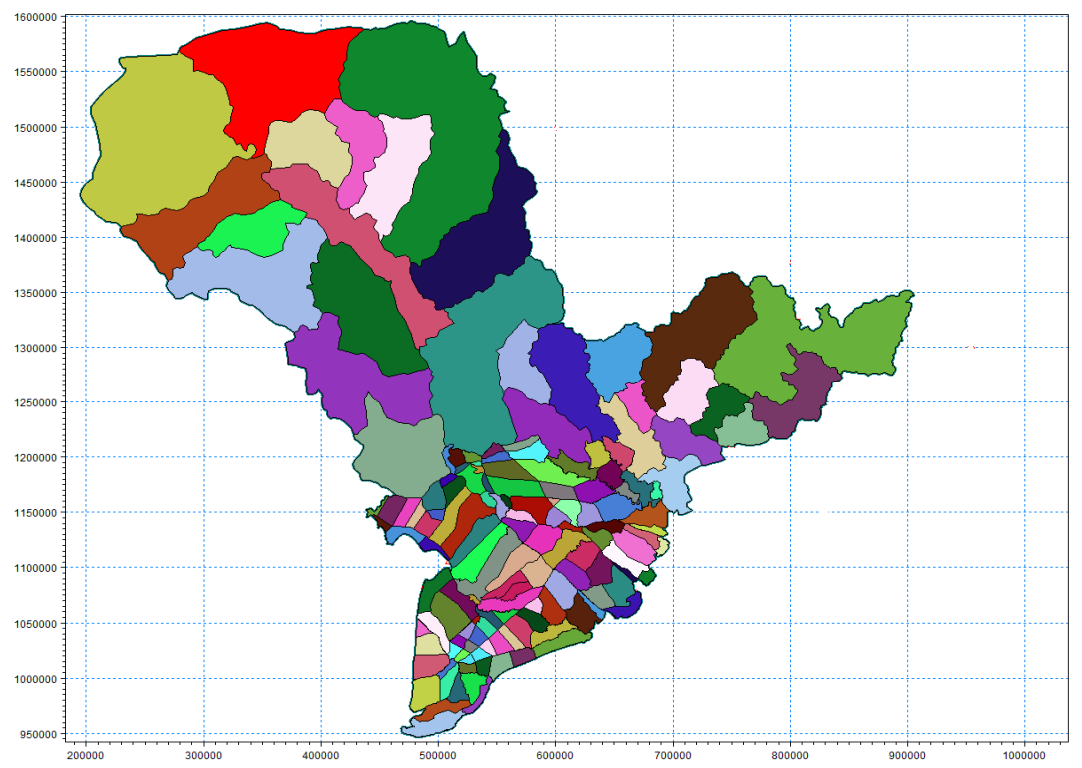

Hình 3. Sơ đồ tính toán Mike NAM vùng châu thổ Mê Công. 


\section{b. Số liệu đầu vào}

Số liệu đầu vào của mô hình Mike NAM bao gồm số liệu mưa, số liệu bốc hơi tiềm năng, số liệu lưu lượng dòng chảy thực đo để kiểm chứng mô hình trên phạm vi toán.

Số lượng trạm có dữ liệu mưa ngày được sử dụng trên vùng ĐBSCL là 31 trạm, lưu vực sông Đồng Nai-Sài Gòn là 24 trạm và phần diện tích phía Campuchia là 10 trạm. Số liệu bốc hơi được sử dụng trên miền đồng bằng LVS Cửu Long là 13 trạm khí tượng của 13 tỉnh thuộc mạng quan trắc quốc gia $[8,13]$, phía Campuchia sử dụng trạm đại diện là Pnomepenh [12].

\section{c. Hiệu chỉnh và kiểm định mô hình}

Đối với các lưu vực phía Campuchia, lưu lượng dòng chảy được hiệu chỉnh thông qua lưu lượng trạm Kompong Thom (sông Stung Sen chảy vào hồ Tonle Sap Flv $=14.000 \mathrm{~km}^{2}$ ) 12. Bộ thông số đã hiệu chỉnh, kiểm định cho kết quả tin cậy được mượn cho các lưu vực lân cận sau khi hiệu chỉnh các thông số liên quan đến nước ngầm và thời gian trễ dòng chảy mặt. Kết quả hiệu chỉnh và kiểm định cho các năm 2000 và 2001-2002 được trình bày trong Hình 4.
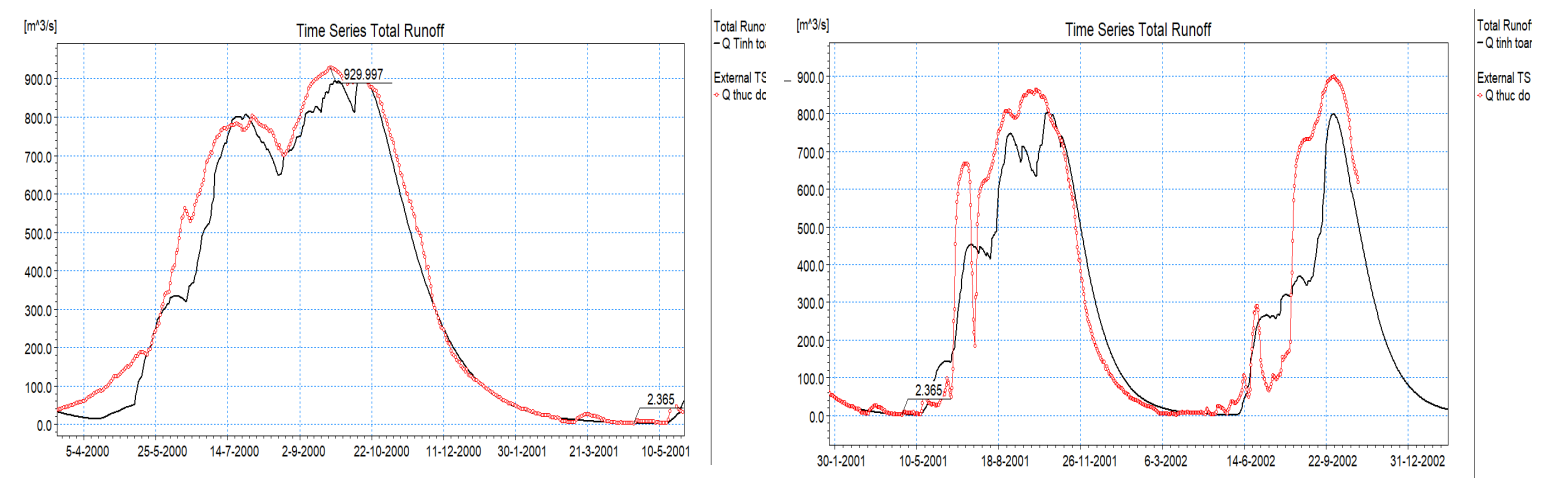

Hình 4. Biểu đồ so sánh đường quá trình lưu lượng tính toán từ MIKE NAM và thực đo tại trạm Kompong Thom: (a) kết quả hiệu chỉnh cho năm 2000; (b) kết quả kiểm định cho các năm 20012002.

Đối với các tiểu lưu vực thuộc vùng ĐBSCL, do các trạm đo lưu lượng đều nằm trên các sông chính (sông Tiền, sông Hậu) do đó không thể sử dụng để hiệu chỉnh mô hình. Đối với các tiểu lưu vực này các thông số được xác định thông qua bản đồ đất (năm 2000) và sử dụng đất (năm 2017) [8]. Phân tích bản đồ đất cho thấy vùng ĐBSCL chủ yếu là nhóm đất phèn, nhiễm mặn và một phần đất phù sa. Các loại đất này tính thấm tương đối kém nên dễ hình thành dòng chảy mặt từ mưa. Từ bản đồ sử dụng đất tiến hành xác định các loại sử dụng đất chính nằm trong các tiểu lưu vực và tỷ lệ diện tích chiếm hữu của chúng để tính toán hệ số dòng chảy bình quân gia quyền theo diện tích. Hệ số chỉ ra khả năng sinh dòng chảy từ mưa của các loại hình sử dụng đất này có thể tham khảo tại Phụ lục B-TCVN 10406-2015.

\section{d. Kết quả đầu ra của mô hình Mike NAM}

Dựa trên phân chia các tiểu lưu vực Mike NAM tính toán được lượng mưa bình quân của các tiểu lưu vực này theo phương pháp đa giác Theissen. Kết quả đã xác định được tài nguyên nước mưa của 120 tiểu lưu vực và được tổng hợp cho 4 vùng quy hoạch.

Kết quả đầu ra đối với mô phỏng dỏng chảy sinh ra từ mưa, bốc hơi của Mike NAM là số liệu chuỗi dòng chảy ngày tại cửa ra của các tiểu lưu vực trong giai đoạn mô phỏng. Kết quả lượng mưa bình quân, dòng chảy đầu ra của các lưu vực được tổng hợp tính toán thống kê để xác định các đặc trưng về tổng lượng, phân phối tháng, mùa cho 4 vùng quy hoạch. 


\subsubsection{Thiết lập mô hình thủy lực mạng sông Mike 11HD}

Để tính toán tài nguyên nước từ các sông chính, tác giả đã sử dụng phần mềm mô hình thủy lực Mike 11HD. Đây là phần mềm có xuất xứ từ Đan Mạch do DHI phát triển dưới dạng thương mại hóa, có những ưu điểm vượt trội đã và đang được áp dụng rất rộng rãi ở Việt Nam cho kết quả đáng tin cậy [18].

a. Sơ đồ mạng thủy lực tính toán

Do đặc điểm của ĐBSCL là vùng đồng bằng ảnh hưởng mạnh bởi thủy triều. Ảnh hưởng này vượt qua biên giới Việt Nam-Campuchia, do đó điều kiện biên dòng chảy tại Tân Châu và Châu Đốc sẽ không phản ánh được chính xác lưu lượng từ thượng nguồn, cùng với đó vào mùa lũ, lượng lũ tràn qua biên giới về vùng Đồng Tháp Mười và tứ giác Long Xuyên rất lớn vì vậy việc mô phỏng hệ thống cần kéo dài sơ đồ sang phía Campuchia để loại bỏ ảnh hưởng của thủy triều và đảm bảo cân bằng lượng nước toàn bộ hệ thống sông.

Sơ đồ mạng thủy lực trong bài toán này được thiết lập bao gồm toàn bộ các sông chính của Đồng bằng châu thổ Mê Công từ hạ lưu Kratie (Campuchia) đến cửa sông (biển Đông). Các sông chính được số hóa trong mô hình thủy lực bao gồm sông Tiền (Mê công), sông Hậu (Bassac), sông Vàm Nao, sông Cổ Chiên, sông Hàm Luông và hơn 400 sông kênh trục nội vùng khác để đáp ứng điều kiện về phân lưu. Ngoài ra, mạng thủy lực cũng được mở rộng để diễn toán điều kiện biên của hệ thống sông Đồng Nai (Hình 5).

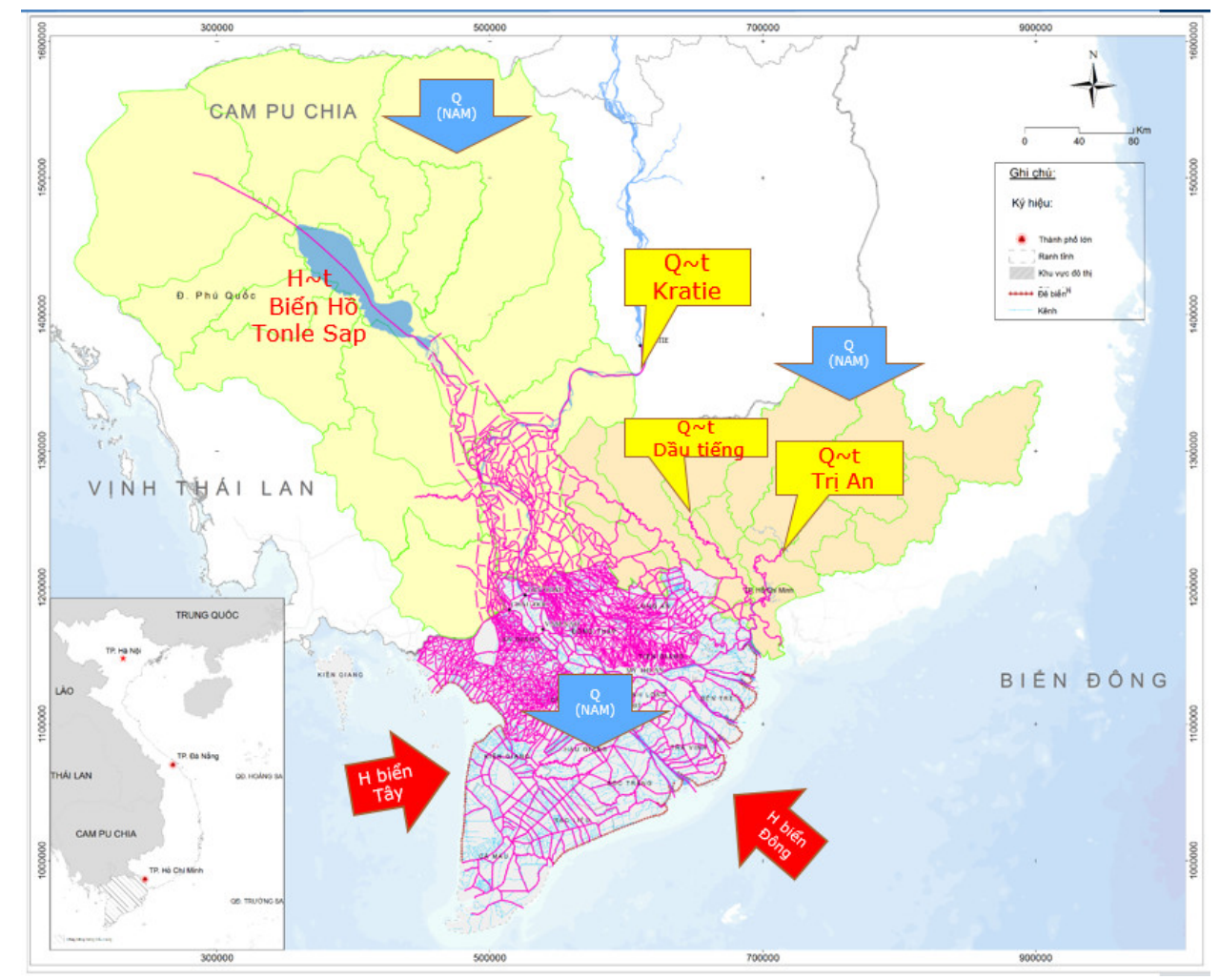

Hình 5. Sơ đồ các lưu vực thủy văn và sơ đồ mạng thủy lực tính toán bằng Mike 11 HD.

Theo yêu cầu của bài toán về tài nguyên nước, mô hình được mô phỏng liên tục với chuỗi số liệu cả năm. Hệ thống công trình cống, đập ngăn mặn vào mùa khô gồm100 cống lớn, nhỏ và các đập tràn Trà Sư, Tha La, Ba Lai được thiết lập để tích trữ nước ngọt, vào mùa lũ các công trình được mở thoáng hoặc ngăn triều theo quy trình vận hành của hệ thống. Đối với dòng chảy mùa lũ, dòng chảy tràn đồng được mô phỏng bằng hệ thống các ô trữ nước phía đồng bằng ngập lũ Campuchia và 2 vùng ngập lũ chính của ĐBSCL là vùng Đồng Tháp Mười và Tứ giác Long Xuyên. 
b. Số liệu đầu vào cho mô hình

Số liệu sử dụng cho mô hình thủy lực Mike 11HD bao gồm số liệu về lưu lượng dòng chảy ngày tại biên sông chính, lưu lượng dòng chảy nhập lưu nhánh sông từ Mike NAM và số liệu mực nước triều từng giờ tại cửa sông phía biển Đông và biển Tây.

Điều kiện biên của mô hình được xác định là các vị trí đầu vào của sông (biên $Q$ ) tại Kratie, Biển Hồ, hạ lưu hồ Trị An, Thác Mơ, Dầu Tiếng và cửa ra của sông (biên $H$ ) tại các cửa sông phía biển Đông và biển Tây. Đối với dòng chảy khu giữa, quá trình lưu lượng dòng nhập lưu khu giữa do mưa rơi trên 149 tiểu lưu vực được tính từ mô hình thủy văn Mike NAM. Chi tiết sơ đồ thủy lực mạng lưới sông kênh trục toàn bộ vùng đồng bằng châu thổ Mê Công được trình bày trong Hình 5 .

c. Hiệu chỉnh và kiểm định mô hình

Trong bài toán tài nguyên nước, để mô hình đảm bảo độ tin cậy, các trạm thủy văn được sử dụng để kiểm tra độ tin cậy về lưu lượng tính toán từ mô hình so với số liệu thực đo, bao gồm Tân Châu, Mỹ Thuận trên sông Tiền, Châu Đốc, Cần Thơ trên sông Hậu và Vàm Nao trên sông Vàm Nao (Hình 6).

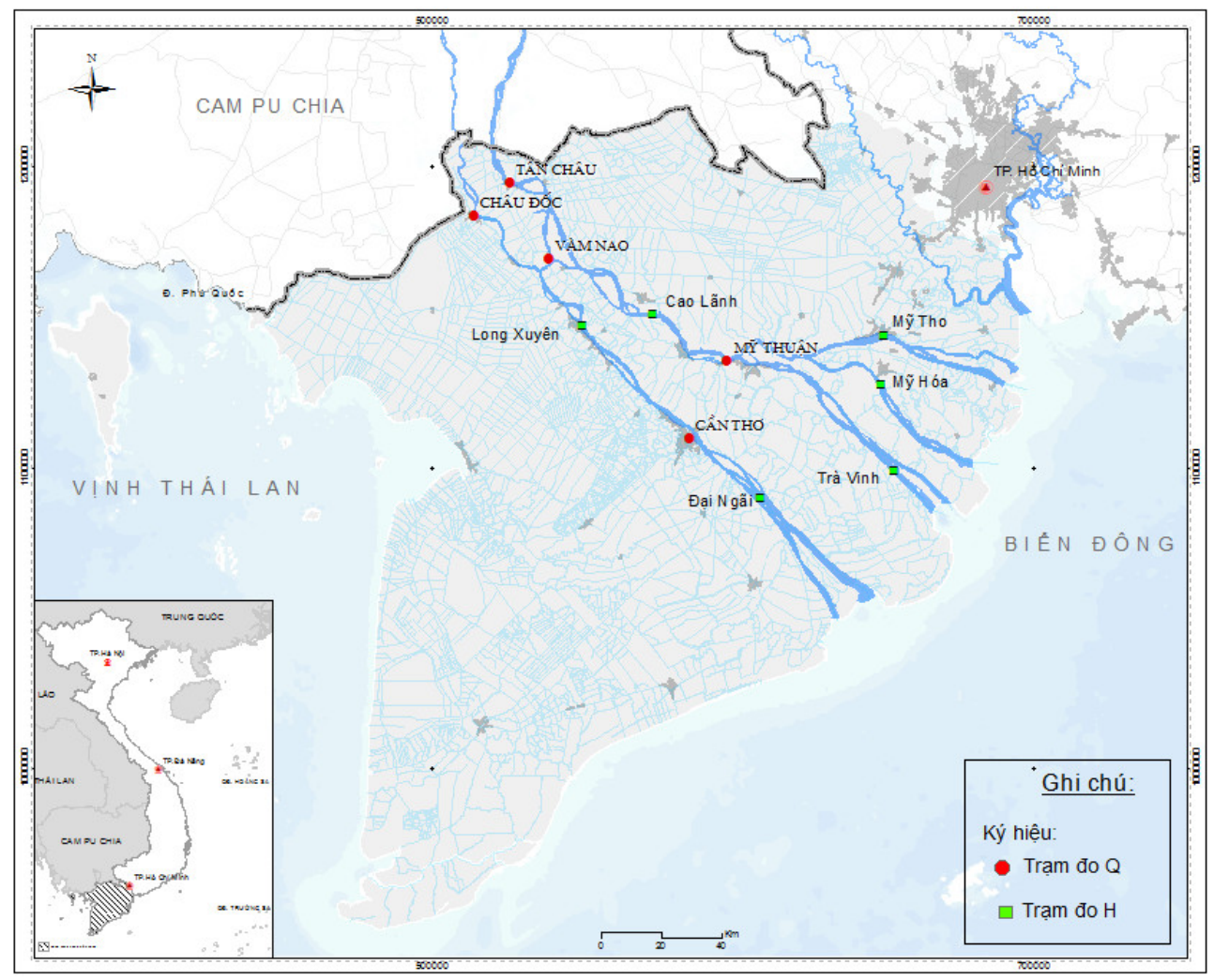

Hình 6. Sơ đồ vị trí kiểm tra lưu lượng dòng chảy tính toán và thực đo trên các sông chính.

Để xác định các thông số mô hình, giai đoạn từ 2000-2008 được sử dụng để hiệu chỉnh các thông số. Đặc điểm trong chuỗi dòng chảy giai đoạn này là có các năm lũ lớn nhỏ khác nhau sẽ kiểm soát được tổng lượng nước những năm nhiều nước, ít nước. Việc hiệu chỉnh mô hình chủ yếu thông qua việc thử sai giá trị độ nhám của mô hình. Kết quả lưu lượng đầu ra so sánh với số liệu thực được đánh giá bằng các chỉ tiêu sai số đường quá trình gồm chỉ tiêu NASH và hệ số tương quan $\mathrm{R}$. Sau khi các sai số đạt yêu cầu, mô hình được kiểm định với chuỗi số liệu thực đo từ 2011-2019.

Kết quả tính toán lưu lượng dòng chảy tháng được mô phỏng bằng mô hình Mike 11HD so với thực đo là tương đối tốt. Về lưu lượng có thể thấy rằng quá trình lưu lượng dòng chảy tháng ở bước hiệu chỉnh và kiểm định mổ hình tại 5 trạm trên dòng chính tương đối phù hợp 
dạng đường quá trình lên xuống, độ tương quan cao $(>0,95)$, chỉ số NASH đạt trên 0,84 . Như vậy, mô hình đáp ứng tốt cho bài toán tính toán tài nguyên nước mặt từ các sông chính tại vùng ĐBSCL theo từng tháng khác nhau. Chi tiết các chỉ tiêu sai số được tính toán trình bày tại Bảng 1 .

Bảng 1. Kết quả đánh giá các chỉ tiêu sai số mô phỏng của mô hình.

\begin{tabular}{rllccccc}
\hline \multirow{2}{*}{ STT } & \multirow{2}{*}{ Tên trạm } & \multirow{2}{*}{ Sông } & \multicolumn{2}{c}{ Hiệu chỉnh } & \multicolumn{2}{c}{ Kiểm định } & \multirow{2}{*}{ Đánh giá } \\
\cline { 4 - 6 } & & & $\mathbf{R}$ & Nash & $\mathbf{R}$ & Nash & \\
\hline 1 & Tân Châu & Tiền & 0,99 & 0,98 & 0,99 & 0,98 & Tin cậy cao \\
2 & Mỹ Thuận & Tiền & 0,99 & 0,97 & 0,99 & 0,97 & Tin cậy cao \\
3 & Châu Đốc & Hậu & 0,99 & 0,96 & 1,00 & 0,99 & Tin cậy cao \\
4 & Cần Thơ & Hậu & 0,99 & 0,97 & 0,99 & 0,99 & Tin cậy cao \\
5 & Vàm Nao & Vàm Nao & 0,99 & 0,98 & 0,99 & 0,98 & Tin cậy cao \\
\hline
\end{tabular}

Ghi chú: R: Hệ số tuoong quan đơn.

Nash: Chỉ tiêu sai số Nash-suttcliff.

Kết quả so sánh lưu lượng dòng chảy tháng giai đoạn hiệu chỉnh và kiểm định mô hình Mike 11HD được trình bày trong Hình 7.

\begin{tabular}{|c|c|c|c|}
\hline Vị trí & Hiệu chỉnh 2000-2008 & & Kiểm định 2011-2019 \\
\hline Châu & (100000000 & 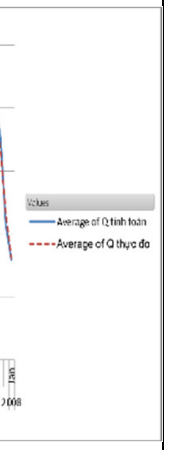 & 20000 \\
\hline Đốc & 2000 & 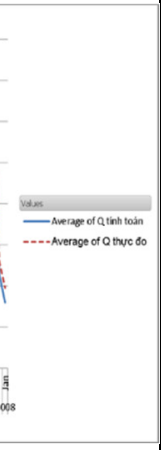 & (2000 \\
\hline Vàm & 2000 & 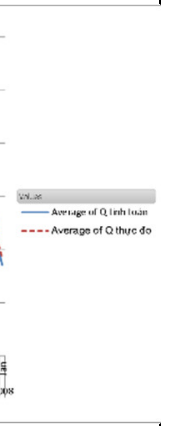 & 2000 \\
\hline
\end{tabular}




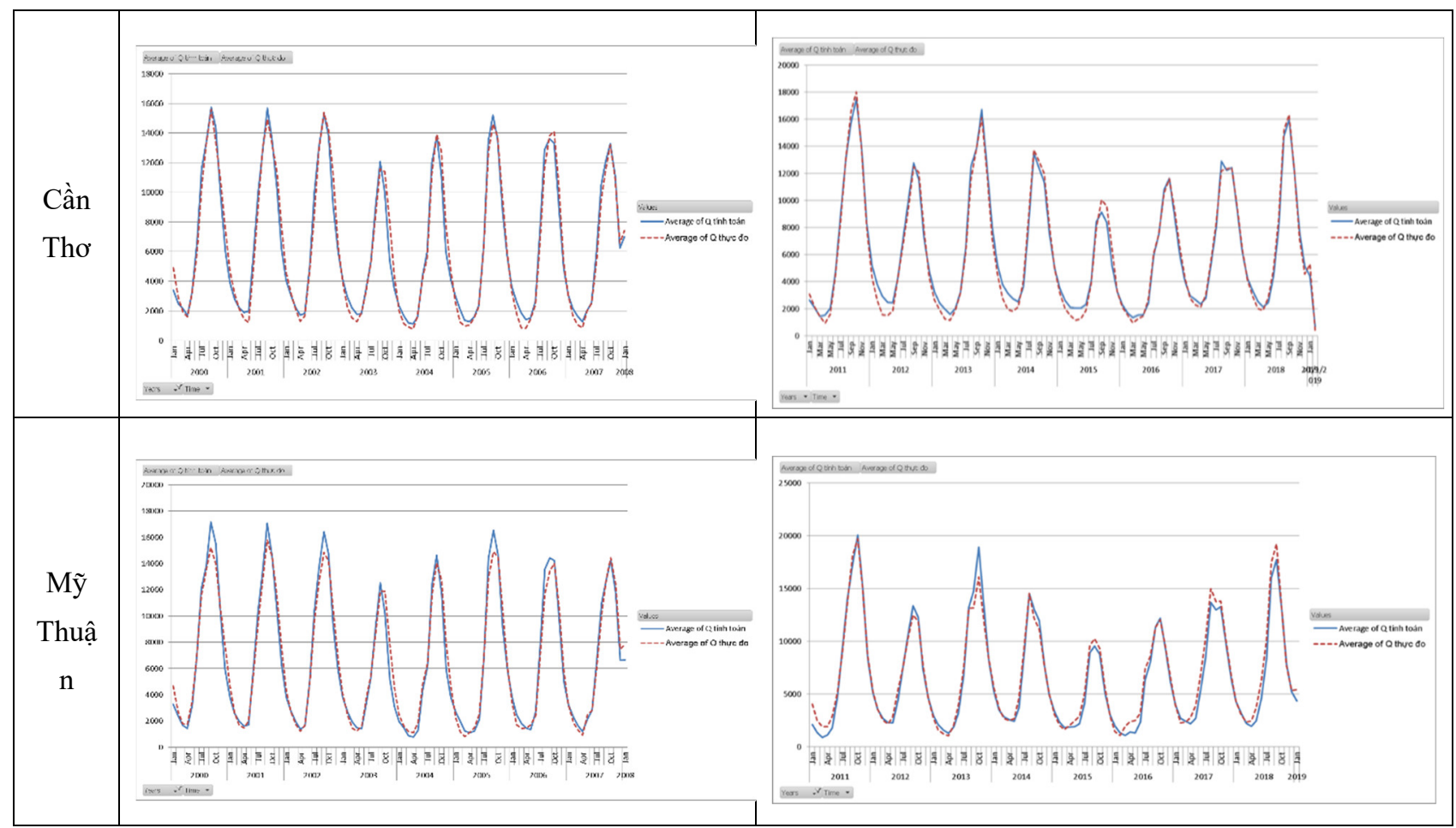

Hình 7. Biểu đồ so sánh lưu lượng tính toán bằng Mike $11 \mathrm{HD}$ và thực đo tại 5 trạm trên các sông chính.

\section{Kết quả nghiên cứu và thảo luận}

\subsection{Tài nguyên nước mưa}

\subsubsection{Tổng lượng tài nguyên nước mưa}

Theo số liệu quan trắc từ 1980-2019 [11], lượng mưa năm tại 31 trạm mưa trên LVSCL dao động từ 1223-2360 mm, trong đó trạm có lượng mưa năm lớn nhất là Cà Mau (2360 $\mathrm{mm})$, trạm thấp nhất là Tân Châu $(1223 \mathrm{~mm})$, tính trung bình theo số lượng trạm thì có thể thấy lượng mưa bình quân năm của LVSCL là $1646 \mathrm{~mm}$ tương ứng với tổng lượng 65,0 tỷ m3 nước mưa. Phương pháp trên đơn thuần chỉ tính bình quân theo số lượng trạm do đó độ tin cậy không cao nếu sự phân bố vị trí trạm đo không đều trên toàn vùng.

Sử dụng mô hình Mike NAM đã thiết lập ở trên để tính toán cho 120 tiểu lưu vực. Kết quả tính trọng số mưa theo đa giác Theissen trong mô hình Mike NAM cho thấy lượng mưa bình quân trên toàn LVSCL là $1733 \mathrm{~mm}$, tương đương với tổng lượng tài nguyên nước mưa là 68,4 tỷ $\mathrm{m}^{3}$, tức chiếm khoảng $10,5 \%$ tổng tài nguyên nước mưa của nước ta Error! Reference source not found.. Lượng mưa phân bố không đồng đều trên toàn vùng, vùng có mưa lớn trên $2000 \mathrm{~mm}$ tập trung ở khu vực ven biển từ Cà Mau đến Kiên Giang, vùng có lượng mưa dưới $1500 \mathrm{~mm}$ chủ yếu là vùng dọc sông Tiền từ Tân Châu đến Biển Đông.

Theo chỉ tiêu "vượt tổn thất" với tần suất xuất hiện $\mathrm{P}>75 \%$ đối với các trạm mưa trong LVSCL có thể xác định mùa mưa trên lưu vực bắt đầu từ tháng $\mathrm{V}$ đến tháng $\mathrm{XI}$, mùa khô gồm các tháng còn lại trong năm kéo dài từ tháng XII năm trước đến tháng IV của năm sau. Sự phân hóa giữa mùa khô và mùa mưa rất rõ ràng, mùa khô trên lưu vực kéo dài 5 tháng với lượng mưa mùa khô chỉ chiếm khoảng từ $6-10 \%$ tổng lượng mưa cả năm, trong khi đó mùa mưa kéo dài 7 tháng với lượng mưa chiếm đến $90-94 \%$. Chi tiết lượng mưa năm, mùa và tỷ lệ lượng mưa mùa so với mưa năm trong thời kỳ 1980-2019 được trình bày trong Bảng 2 . Bảng 3 trình bày tổng lượng tài nguyên nước mưa được tổng hợp phân theo 04 vùng quy hoạch của ngành thủy lợi hiện có trên LVSCL. Hình 8 trình bày sơ đồ đẳng trị mưa năm và giá trị lượng mưa bình quân năm tại trạm quan trắc giai đoạn 1980-2019 LVSCL. 
Bảng 2. Lượng mưa năm, mùa và tỷ lệ lượng mưa mùa so với cả năm tại các trạm quan trắc đại diện tại 13 tỉnh LVSCL.

\begin{tabular}{|c|c|c|c|c|c|c|c|c|c|}
\hline \multirow[b]{2}{*}{ TT } & \multirow[b]{2}{*}{ Tên Trạm } & \multirow[b]{2}{*}{ Tỉnh } & \multirow{2}{*}{$\begin{array}{c}\text { Lượng } \\
\text { mưa năm } \\
\text { (mm) }\end{array}$} & \multicolumn{3}{|c|}{ Mùa mưa } & \multicolumn{3}{|c|}{ Mùa khô } \\
\hline & & & & Tháng & $\begin{array}{c}\text { Lường } \\
\text { mưa }\end{array}$ & $\begin{array}{c}\text { Tỷ lệ } \\
\text { \% }\end{array}$ & Tháng & $\begin{array}{c}\text { Lương } \\
\text { mưa }\end{array}$ & $\begin{array}{c}\text { Tỷ lệ } \\
\%\end{array}$ \\
\hline 1 & Tân An & Long An & 1585 & V-XI & 1452 & $92 \%$ & XII-IV & 133 & $8,4 \%$ \\
\hline 2 & Mỹ Tho & Tiền Giang & 1458 & V-XI & 1359 & $93 \%$ & XII-IV & 99 & $6,8 \%$ \\
\hline 3 & Cao Lãnh & Đồng Tháp & 1475 & $\mathrm{~V}-\mathrm{XI}$ & 1336 & $91 \%$ & XII-IV & 139 & $9,4 \%$ \\
\hline 4 & Ba Tri & Bến Tre & 1492 & $\mathrm{~V}-\mathrm{XI}$ & 1406 & $94 \%$ & XII-IV & 86 & $5,8 \%$ \\
\hline 5 & Vĩnh Long & Vĩnh Long & 1423 & $\mathrm{~V}-\mathrm{XI}$ & 1314 & $92 \%$ & XII-IV & 109 & $7,6 \%$ \\
\hline 6 & Trà Vinh & Trà Vinh & 1457 & $\mathrm{~V}-\mathrm{XI}$ & 1375 & $94 \%$ & XII-IV & 82 & $5,6 \%$ \\
\hline 7 & Long Xyên & An Giang & 1457 & $\mathrm{~V}-\mathrm{XI}$ & 1311 & $90 \%$ & XII-IV & 146 & $10,0 \%$ \\
\hline 8 & Rạch Giá & Kiên Giang & 2184 & $\mathrm{~V}-\mathrm{XI}$ & 1989 & $91 \%$ & XII-IV & 195 & $8,9 \%$ \\
\hline 9 & Cần Thơ & TP.Cần Thơ & 1605 & $\mathrm{~V}-\mathrm{XI}$ & 1479 & $92 \%$ & XII-IV & 126 & $7,9 \%$ \\
\hline 10 & Vị Thanh & Hậu Giang & 1845 & $\mathrm{~V}-\mathrm{XI}$ & 1681 & $91 \%$ & XII-IV & 163 & $8,9 \%$ \\
\hline 11 & Sóc Trăng & Sóc Trăng & 1868 & $\mathrm{~V}-\mathrm{XI}$ & 1735 & $93 \%$ & XII-IV & 134 & $7,2 \%$ \\
\hline 12 & Bạc Liêu & Bạc Liêu & 1953 & $\mathrm{~V}-\mathrm{XI}$ & 1829 & $94 \%$ & XII-IV & 124 & $6,3 \%$ \\
\hline 13 & Cà Mau & Cà Mau & 2360 & $\mathrm{~V}-\mathrm{XI}$ & 2128 & $90 \%$ & XII-IV & 232 & $9,8 \%$ \\
\hline
\end{tabular}

Bảng 3. Tổng lượng tài nguyên nước mưa phân theo 04 vùng quy hoạch của ngành thủy lợi hiện có trên LVSCL.

\begin{tabular}{|c|c|c|c|c|c|c|c|}
\hline \multirow[b]{2}{*}{ TT } & \multirow[b]{2}{*}{ Tên vùng } & \multirow{2}{*}{$\begin{array}{l}\text { Lượng mưa } \\
\text { bình quân } \\
\text { (mm) }\end{array}$} & \multirow{2}{*}{$\begin{array}{c}\text { Tổng TNN } \\
\text { mưa } \\
\text { (triệu } \mathbf{m}^{3} \text { ) }\end{array}$} & \multicolumn{2}{|c|}{ Mùa mưa $(\mathrm{V}-\mathrm{XI})$} & \multicolumn{2}{|c|}{ Mùa khô (XI-VI) } \\
\hline & & & & $\begin{array}{c}\mathrm{W} \\
\text { (triệu } \mathbf{m}^{3} \text { ) }\end{array}$ & Tỷ lệ \% & $\begin{array}{c}\mathrm{W} \\
\text { (triệu } \mathbf{m}^{\mathbf{3}} \text { ) }\end{array}$ & Tỷ lệ \% \\
\hline 1 & Tứ giác Long Xuyên & 1.622 & 8.073 & 7.044 & $87,2 \%$ & 1.029 & $12,8 \%$ \\
\hline 2 & Bán đảo Cà Mau & 2.015 & 34.432 & 30.986 & $90,0 \%$ & 3.446 & $10,0 \%$ \\
\hline 3 & Giữa sông Tiền-Hậu & 1.493 & 12.134 & 10.921 & $90,0 \%$ & 1.213 & $10,0 \%$ \\
\hline \multirow[t]{2}{*}{4} & Tả sông Tiền & 1.485 & 13.788 & 12.368 & $89,7 \%$ & 1.420 & $10,3 \%$ \\
\hline & Tổng & 1,733 & 68,428 & 61,320 & $90 \%$ & 7,108 & $10 \%$ \\
\hline
\end{tabular}

\subsubsection{Phân phối mưa theo tháng}

Không chỉ có mưa năm phân hóa rõ nét theo mùa mà còn theo từng tháng trong năm. Dựa theo kết quả tính toán phân phối mưa theo tháng có thể thấy: Tháng có lượng mưa cao nhất thường rơi vào tháng $X$ trong năm với tổng lượng mưa chiếm từ $13-23 \%$ tổng lượng mưa năm, tháng có lượng mưa nhỏ nhất thường rơi vào tháng II với tổng lượng mưa chiếm dưới 10\% tổng lượng mưa năm (Hình 9). 


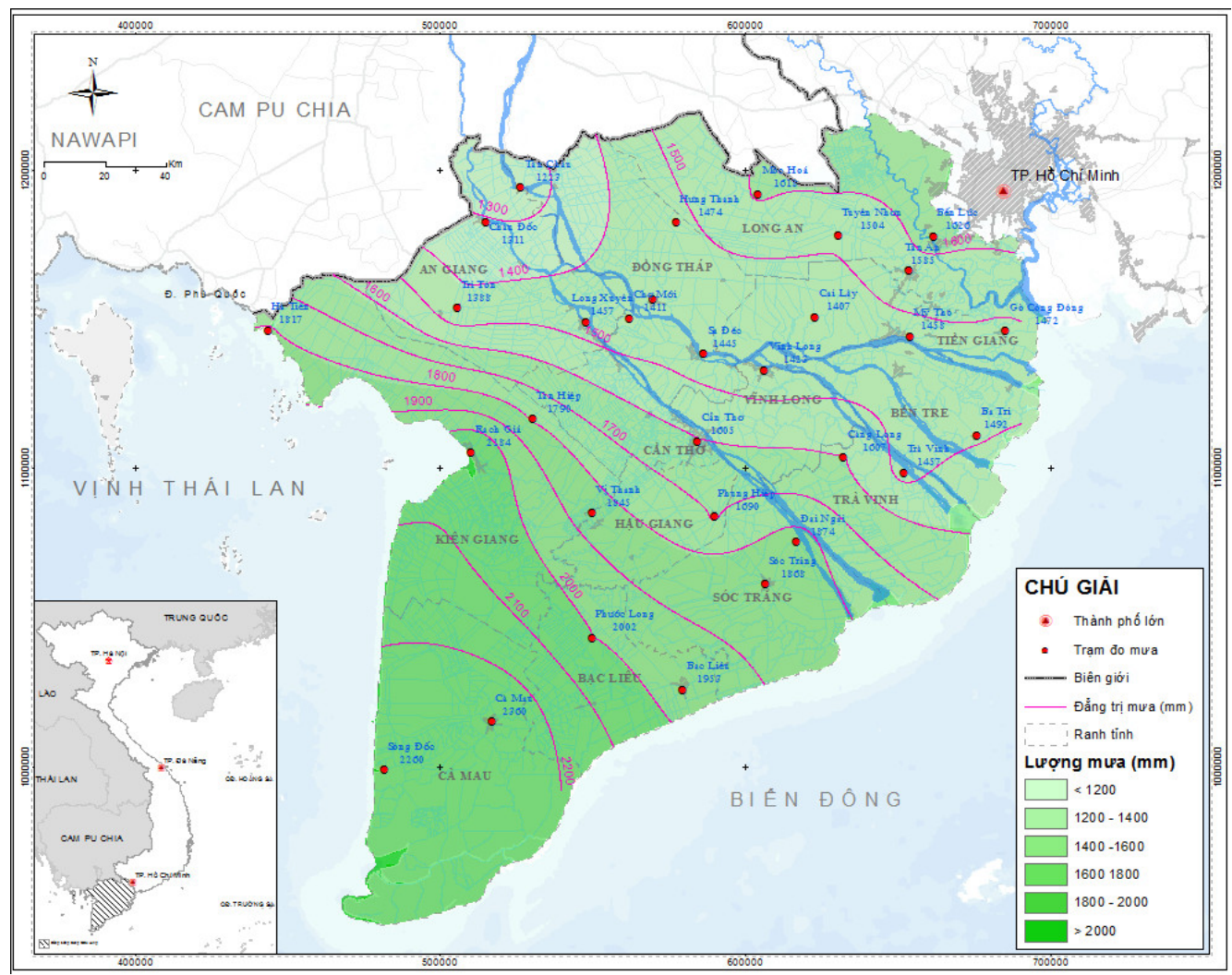

Hình 8. Sơ đồ đẳng trị mưa năm và giá trị lượng mưa bình quân năm tại trạm quan trắc giai đoạn 1980-2019 LVSCL.

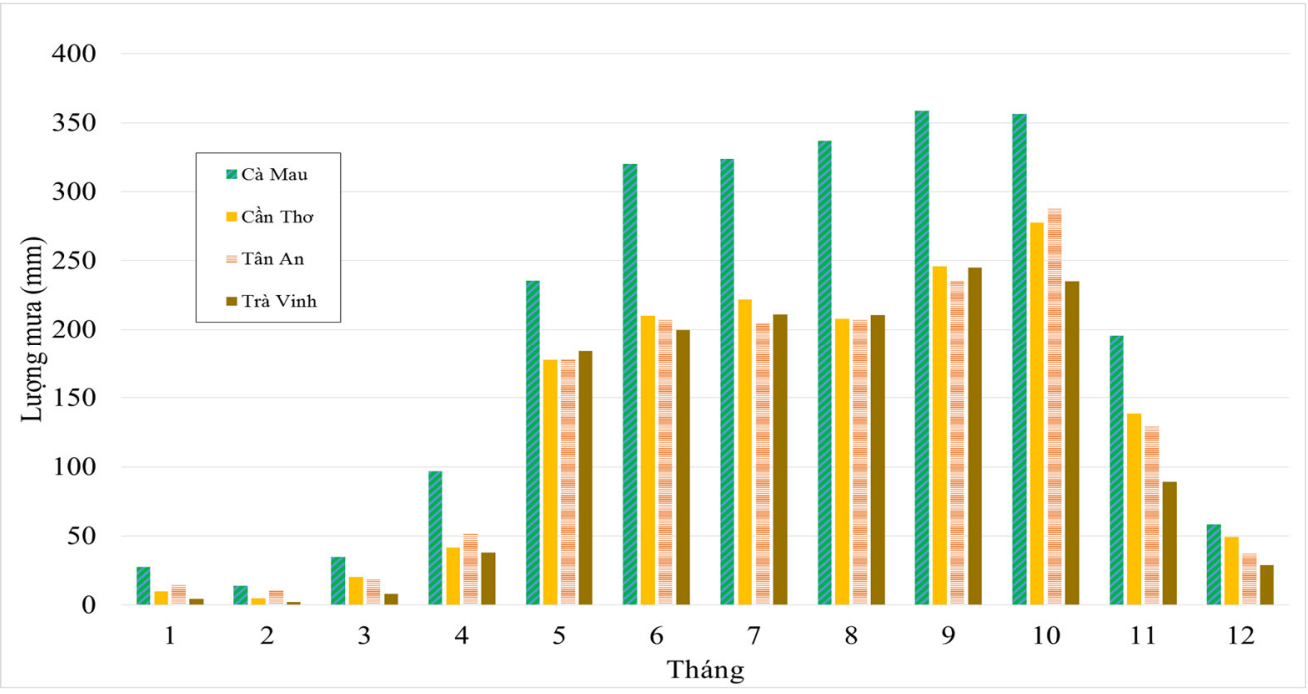

Hình 9. Biểu đồ phân phối lượng mưa theo tháng tại các trạm điển hình của LVSCL.

\subsection{Tài nguyên nước mặt}

\subsubsection{Tài nguyên nước mặt nội sinh}

Kết quả tính toán từ mô hình NAM tại Bảng 4 cho thấy tổng lượng tài nguyên nước mặt từ mưa nội sinh trên toàn bộ LVSCL là 27.9 tỷ $\mathrm{m}^{3}$, tương đương lưu lượng dòng chảy tổng cộng toàn vùng là $946 \mathrm{~m}^{3} / \mathrm{s}$. Sự phân phối mùa khá rõ rệt, mùa cạn từ tháng VI-XI gần như không có dòng chảy, trong khi đó nguồn nước mặt chủ yếu trong mùa mưa chiếm trên $90 \%$ tổng lượng dòng chảy mặt sản sinh từ mưa. 
Bảng 4. Tổng lượng nước nội sinh từ mưa trên 04 vùng tính toán.

\begin{tabular}{|c|c|c|c|c|c|c|}
\hline \multirow{2}{*}{ TT } & \multirow{2}{*}{ Tên vùng } & \multirow{2}{*}{$\begin{array}{c}\text { Tổng } \\
\left(\text { triệu m m }{ }^{3}\right)\end{array}$} & \multicolumn{2}{|c|}{ Mùa lũ (VI-XI) } & \multicolumn{2}{|c|}{ Mùa cạn (XII-V) } \\
\hline & & & W (triệu m m) & Tỷ lệ \% & W (triệu m m) & Tỷ lệ \% \\
\hline 1 & Tứ giác Long Xuyên & 3.153 & 2.898 & $91,9 \%$ & 255 & $8,1 \%$ \\
\hline 2 & Bán đảo Cà Mau & 16.801 & 15.674 & $93,3 \%$ & 1.127 & $6,7 \%$ \\
\hline 3 & Giữa sông Tiền-Hậu & 4.526 & 4.281 & $94,6 \%$ & 244 & $5,4 \%$ \\
\hline 4 & Tả sông Tiền & 5.457 & 5.208 & $95,4 \%$ & 249 & $4,6 \%$ \\
\hline & Tổng & 29.937 & 28.061 & $94 \%$ & 1.876 & $6 \%$ \\
\hline
\end{tabular}

\subsubsection{Tài nguyên nước từ sông chính}

Trên cơ sở bộ thông số được xác định: sử dụng chuỗi dữ liệu mưa, lưu lượng tại Kratie và mực nước tại các cửa sông từ năm 2000-2019, tiến hành mô phỏng mô hình Mike 11HD, xác định tổng lượng dòng chảy và lũ tràn qua biên giới Việt Nam-Campuchia. Kết quả cho thấy toàn tuyến biên giới có tổng lượng chảy tràn khoảng 42,9 tỷ $\mathrm{m}^{3}$, trong đó mùa lũ là 40,2 tỷ $\mathrm{m}^{3}$ (chiếm $94 \%$ tổng lượng chảy tràn qua biên giới), trong khi mùa khô lượng nước qua biên giới qua các sông kênh nhánh chỉ khoảng 2,7 tỷ $\mathrm{m}^{3}$ (chiếm $6 \%$ tổng lượng chảy tràn) (Bảng 5). Như vậy, tổng lượng tài nguyên nước mặt đến LVSCL là 470,8 tỷ $\mathrm{m}^{3}$, trong đó lượng nước từ các sông chính là 440,8 tỷ $\mathrm{m}^{3}$ (qua sông Tiền là 321 tỷ $\mathrm{m}^{3}$, qua sông Hậu là 76,9 tỷ $\mathrm{m}^{3}$ và lượng nước chảy tràn qua biên giới là 42,9 tỷ $\mathrm{m}^{3}$ ) và lượng nước nội sinh từ mưa là 29,9 tỷ $\mathrm{m}^{3}$ (Bảng 5). Tỷ lệ lượng nước mặt nội sinh chỉ chiếm $6,4 \%$ tổng lượng nước mặt đến LVSCL, trong đó mùa lũ chiếm khoảng 7,5\% và mùa khô rất nhỏ chỉ 1,9\% (Bảng 6). Trong khi đó tổng lượng dòng chảy ngoại chiếm đến $93,6 \%$, nhưng phân phối hàng tháng cho thấy các tháng mùa khô chỉ đạt $2-6 \%$, mùa lũ từ $8-16 \%$ tổng lượng nước cả năm, đặc biệt dòng chảy mùa lũ thường rất lớn và chủ yếu theo sông chính ra biển nên rất khó sử dụng. Dòng chảy tràn qua biên giới tập trung chủ yếu từ tháng VIII-XI, gây bất lợi cho sản xuất tại vùng Đồng Tháp Mười và Tứ Giác Long Xuyên (Bảng 6). Hình 10 trình bày tổng lượng tài nguyên nước mưa, nước mặt và tỷ lệ của tổng lượng nước mặt toàn LVSCL. Hình 11 trình bày phân phối tổng lượng nước mưa, nước mặt sông chính và chảy tràn biên giới hàng tháng.

Bảng 5. Tổng lượng nước mặt từ sông chính và tràn qua biên giới về LVSCL.

\begin{tabular}{|c|c|c|c|c|c|c|}
\hline \multirow{2}{*}{ STT } & \multirow{2}{*}{ Vị trí } & \multirow{2}{*}{ Tổng } & \multicolumn{2}{|c|}{ Mùa lũ (VI-XI) } & \multicolumn{2}{|c|}{ Mùa cạn (XII-V) } \\
\hline & & & W (tỷ $\left.\mathbf{m}^{3}\right)$ & Tỷ lệ \% & $W\left(t y ̉ ~ m^{3}\right)$ & Tỷ lệ \% \\
\hline & Kratie* & 424,6 & 363,6 & $86 \%$ & 61.0 & $14 \%$ \\
\hline 1 & Tân Châu* & 321,0 & 241,9 & $75 \%$ & 79.1 & $25 \%$ \\
\hline 2 & Châu Đốc* & 76,9 & 61,7 & $80 \%$ & 15.2 & $20 \%$ \\
\hline \multirow[t]{2}{*}{3} & Chảy tràn biên giới & 42,9 & 40,2 & $94 \%$ & 2.7 & $6 \%$ \\
\hline & Tổng & 440.8 & 343,8 & $78 \%$ & 97,0 & $22 \%$ \\
\hline
\end{tabular}

Ghi chú: * Giá trị tính tì số liệu thực đo

Bảng 6. Kết quả tổng lượng tài nguyên nước mưa, nước mặt LVSCL.

\begin{tabular}{ccccc}
\hline STT & Tài nguyên nước & Tổng $\left(\mathbf{t y ̉} \mathbf{~ m}^{\mathbf{3}}\right)$ & Mùa lũ $(\mathbf{V I}-\mathbf{X I})$ & Mùa cạn $(\mathbf{X I I}-\mathbf{V})$ \\
\hline 1 & Tài nguyên nước mưa & 68,4 & 61,3 & 7,1 \\
2 & Tài nguyên nước mặt & 470,8 & 371,9 & 98,9 \\
2.1 & Nước mặt nội sinh & 29,9 & 28,1 & 1,9 \\
& Tỷ lệ & $6,4 \%$ & $7,5 \%$ & $1,9 \%$ \\
\multirow{2}{*}{2.2} & Nước mặt ngoại lai & 440,8 & 343,8 & 97,0 \\
& Tỷ lệ & $93,6 \%$ & $92,5 \%$ & $98,1 \%$ \\
\hline
\end{tabular}




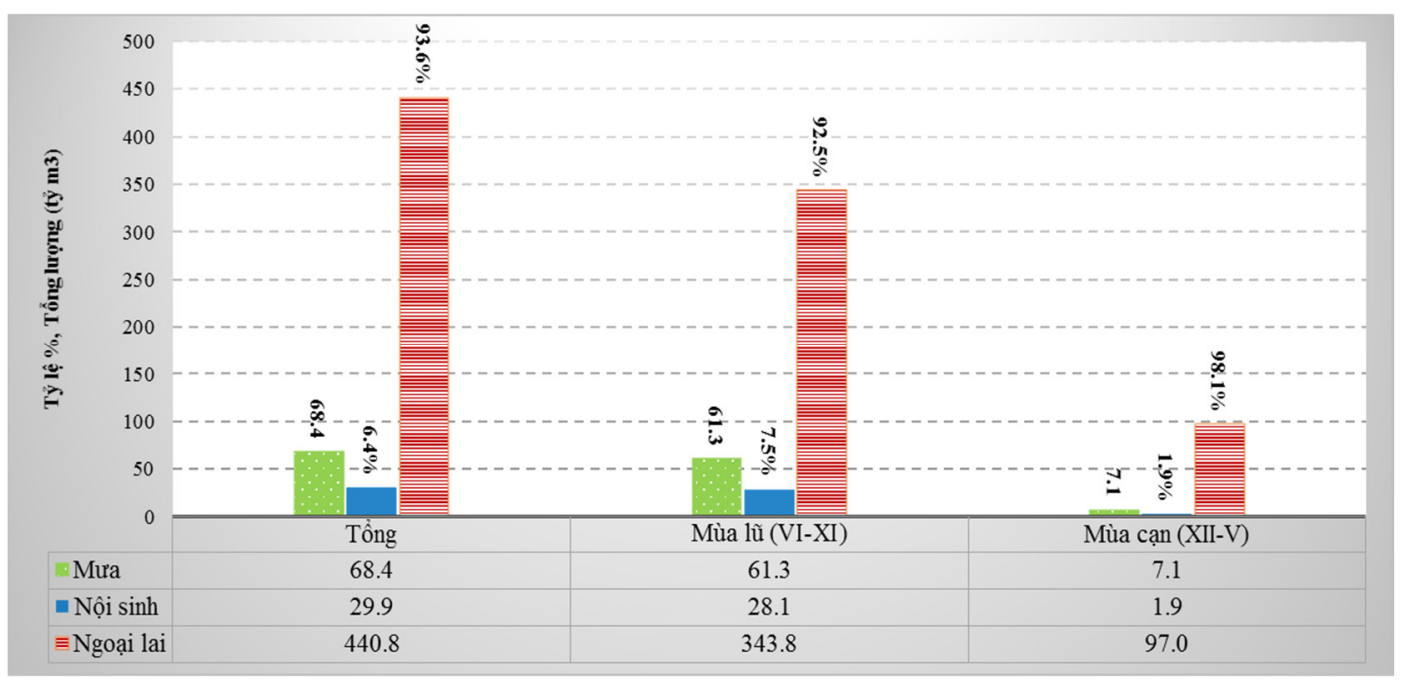

Hình 10. Tổng lượng tài nguyên nước mưa, nước mặt và tỷ lệ của tổng lượng nước mặt toàn LVSCL.

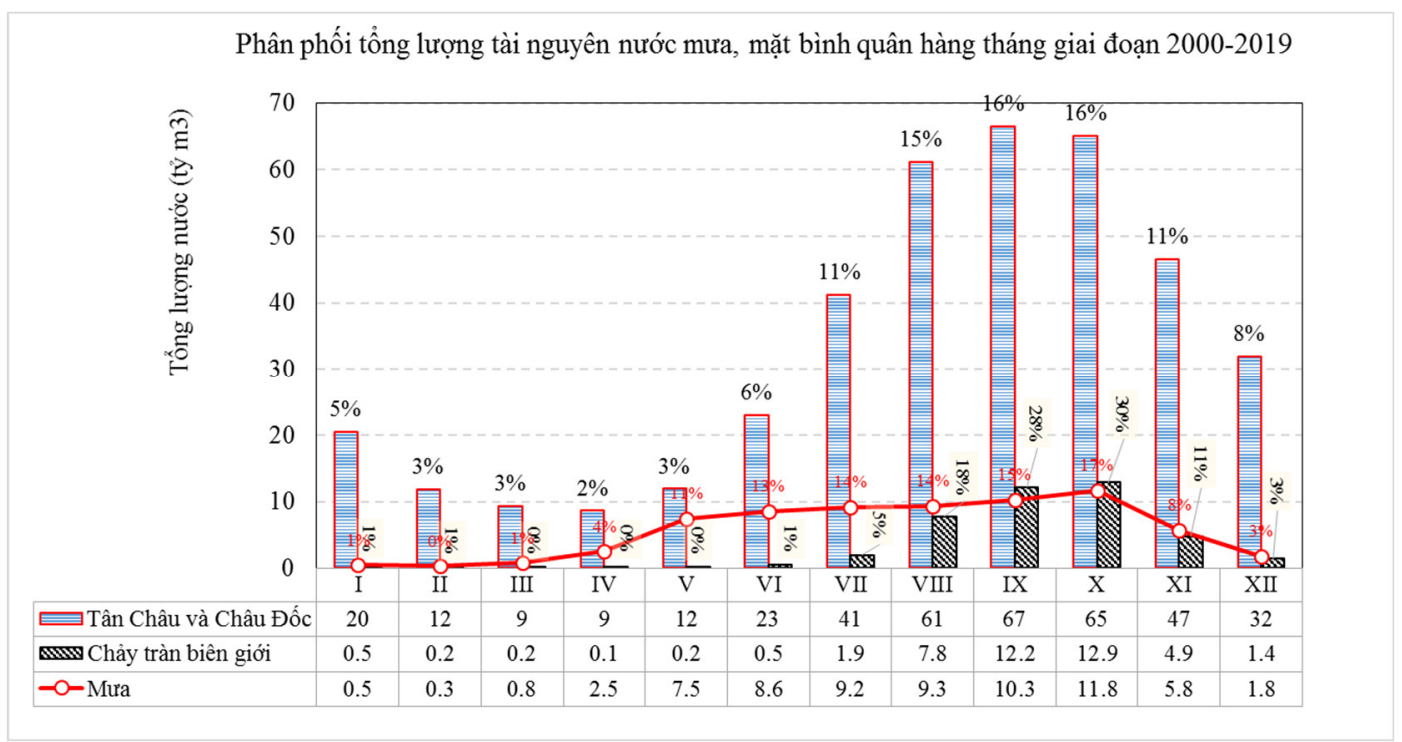

Hình 11. Phân phối tổng lượng nước mưa, nước mặt sông chính và chảy tràn biên giới hàng tháng.

\section{Kết luận}

Bài báo đã tổng hợp, phân tích tài liệu từ 2000-2019 kết hợp với sử dụng công cụ mô hình MIKE-NAM, MIKE 1D đã xây dựng được bộ thông số phù hợp để mô phỏng, tính toán các đặc trưng tài nguyên nước mưa, nước mặt trên LVSCL. Từ những kết quả trên đây rút ra một số kết luận sau:

Đối với LVSCL, bài báo đã nghiên cứu đặc điểm tài nguyên nước mặt trên LVSCL khá hoàn chỉnh, đồng bộ và chi tiết. Các kết quả nghiên cứu được tính toán đảm bảo đủ độ tin cậy, có thể được sử dụng trong công tác quản lý điều hành tác nghiệp cũng như đầu vào cho các nghiên cứu tính toán khác đối với nguồn nước mặt trên lưu vực.

Tài nguyên nước mưa: Tổng lượng tài nguyên nước mưa là 68,4 tỷ $\mathrm{m}^{3}$, trong đó mùa mưa: 61,3 tỷ $\mathrm{m}^{3}$, mùa khô: 7,1 tỷ $\mathrm{m}^{3}$. Lượng mưa mùa mưa chiếm từ $90-94 \%$ tổng lượng mưa năm (tập trung vào tháng IX, X), mùa khô chỉ chiếm khoảng 6-10\% tổng lượng mưa cả năm.

Tài nguyên nước mặt: Tổng lượng dòng chảy năm toàn lưu vực là 471 tỷ $\mathrm{m}^{3}$, tổng lượng dòng chảy mùa cạn là 371,9 tỷ $\mathrm{m}^{3}$ (chiếm $79 \%$ ), mùa lũ là 98,9 tỷ $\mathrm{m}^{3}$ (chiếm $21 \%$ ) so với tổng lượng dòng chảy năm. Tổng lượng nước mặt sinh ra từ mưa nội vùng là 30 tỷ tỷ $\mathrm{m}^{3}$, ngoại lai từ ngoài thượng nguồn là 441 tỷ $\mathrm{m}^{3}$. 
So với các nghiên cứu trước đây $[2,9]$, thì tài nguyên nước ngoại lai đã giảm mạnh, chứng tỏ sự tác động của các công trình thượng nguồn và biển đổi khí hậu đã tác động mạnh mẽ đến du sông Mê Công. Mùa lũ kéo dài 6 tháng (VI-XI), tập trung chủ yếu tháng IX, X, vào mùa cạn lượng nước nội sinh gần như không còn, lượng nước ngoại lai chỉ chiếm từ $2-$ $6 \%$ tổng lượng nước cả năm.

Tài nguyên nước LVSCL có sự phụ thuộc phần lớn vào dòng chảy từ ngoài chảy vào (thượng nguồn), trong khi nguồn nước trên LVSCL thực tế đang phải đối mặt với sự suy giảm về chất lượng và số lượng, bên cạnh đó nhu cầu nước cho phát triển kinh tế càng gia tăng. Để khai thác và sử dụng bền vững tài nguyên nước việc đánh giá tiềm năng nguồn nước để xây dựng kế hoạch, chiến lược phân bổ tài nguyên nước phù hợp là yêu cầu rất cấp thiết. Nghiên cứu sẽ là nguồn thông tin, số liệu thiết yếu và là cơ sở để phục vụ công tác quản lý, quy hoạch và phát triển nguồn nước.

Các kết quả trên được tính toán dựa trên số liệu thực đo, kết hợp với sử dụng mô hình toán thủy văn Mike NAM, thủy lực Mike 11HD được hiệu chỉnh kiểm định tốt, tin cậy. Mặc dù vậy, việc hạn chế vể số liệu đo lưu lượng tại LVS Cửu Long, đặc biệt là các tuyến biên giới Việt Nam-Campuchia nên các kết quả trên phù hợp về mặt tổng lượng nước tháng, mùa, năm. Để có các kết quả tốt nhất, trong nghiên cứu chuyên sâu đối với từng mùa, cực trị thì cần phải có sự đối sánh về dòng chảy biên giới đầy đủ hơn.

Đóng góp của tác giả: Xây dựng ý tưởng nghiên cứu: N.N.H.; Lựa chọn phương pháp nghiên cứu: N.M.T.; H.T.N.M.; Xử lý số liệu: N.M.T.; H.T.N.M.; Chạy mô hình: N.M.T.; N.N.H.; Xử lý GIS và bản đồ: N.M.T.; Phân tích kết quả: N.N.H.; H.T.N.M.; N.M.T.; Viết bản thảo bài báo: N.M.T.; H.T.N.M.; Chỉnh sửa bài báo: N.N.H., H.T.N.M.

Lời cảm ơn: Nội dung bài báo này là một phần kết quả của đề tài ĐTĐL.CN-44/18 do Bộ Khoa học và Công nghệ tài trợ. Nhóm tác giả xin chân thành cảm ơn sự hỗ trợ quý báu này.

Lời cam đoan: Tập thể tác giả cam đoan bài báo này là công trình nghiên cứu của tập thể tác giả, chưa được công bố ở đâu, không được sao chép từ những nghiên cứu trước đây; không có sự tranh chấp lợi ích trong nhóm tác giả.

\section{Tài liệu tham khảo}

1. WUP-JICA. Part III: Hydro-Hydraulic modelling. Vol. I: Main report, Mekong delta flood warning and monitoring system project. 2004, pp. 125.

2. Ủy Hội sông Mê Công (MRC). Nghiên cứu tác động của các công trình thủy điện trên dòng chính sông Mê Công, Tập 1-Mô hình-thiết kế mô hình và mô phỏng. Báo cáo chính, MRC-Viêng Chăn (Lao PDR), 2016, tr. 204.

3. Nhung, N.T.T.; Trí, Đ.Q.; Hải, Đ.V. Nghiên cứu ứng dụng bộ mô hình FEWS xây dựng công cụ dự báo lũ các trạm hạ lưu sông Mê Kông. Tạp chí Khí tượng Thủy văn 2018, 688, 24-35.

4. Thái, T.H.; Tuyển, H.M.; Dũng, L.H.; Tiến, N.X.; Anh, T.Đ. Diễn biến dòng chảy ở Đồng bằng sông Cửu long. Tạp chí Khi tương Thủy Văn 2014, 643, 19-23.

5. Trí, Đ.Q. Úng dụng mô hình Mike 11 mô phỏng và tính toán xâm nhập mặn cho khu vực Nam Bộ. Tạp chí Khí tượng Thủy văn 2016, 671, 39-46.

6. Doan, Q.T.; Nguyen, T.M.L.; Tran, H.T.; Kandasamy, J. Application of 1D-2D coupled modeling in water quality assessment: A case study in Ca Mau Peninsula, Vietnam. Phys. Chem. Earth. A/B/C/ 2019, 113, 83-99.

7. Bộ Xây Dựng. Quy hoạch cấp nước vùng Đồng bằng sông Cửu long đến năm 2030 tầm nhìn đến năm 2050. Báo cáo chính, 2016, tr. 205.

8. Bộ Kế hoạch và Đầu tư. Quy hoạch vùng Đồng bằng sông Cửu Long thời kỳ 20212030, định hướng đến năm 2050. Báo cáo chính, 2021, tr. 599.

9. Thái, T.H. Nghiên cứu ảnh hưởng của biến đổi khí hậu đến sự biến đổi tài nguyên nước đồng bằng sông cửu long. Báo cáo tổng hợp kết quả khoa học công nghệ, 
chương trình $\mathrm{KH} \& \mathrm{CN}$ phục vụ chương trình mục tiêu quốc gia ứng phó với biến đổi khí hậu (BĐKH/11-15). Hà Nội, 2014, tr. 408.

10. Xuân, T.T.; Tuyển, H.M.; Thục, T.; Thái, T.H.; Dũng, N.K. Tài nguyên nước hệ thống sông chính Việt Nam. Sách chuyên khảo NXB KH\&KT, Hà Nội, 2012, tr. 268.

11. Tổng cục Khí tượng Thủy văn (VNMHA). http://kttvqg.gov.vn/

12. https://portal.mrcmekong.org/

13. Trung tâm Quy hoạch và Điều tra tài nguyên nước quốc gia. Lập nhiệm vụ Quy hoạch tài nguyên nước lưu vực sông Cửu Long. Báo cáo thuyết minh, Hà Nội, 2020, tr. 119.

14. Viện Quy hoạch thủy lợi miền nam. Quy hoạch tổng thể thuỷ lợi ĐBSCL trong điều kiện biến đổi khí hậu-nước biển dâng. Báo cáo thuyết minh. TPHCM, 2009, tr. 411.

15. Xuân, T.T.; Thục, T.; Tuyển, H.M. Tác động của biến đổi khí hậu đến tài nguyên nước Việt Nam. Sách chuyên khảo, NXB: KH-KT, Hà Nội, 2011, tr. 268.

16. Bộ Tài nguyên và Môi trường. Báo cáo môi trường quốc gia: Tổng quan về nước mặt Việt Nam. Hà Nội, 2012, tr. 22.

17. Hà, N.N.; Giang, N.T. Tài nguyên nước mặt lưu vực sông Vệ. Tạp chí Khoa học ĐHQGHN: Khoa hoc Tụ nhiên và Công nghệ 2015, 31(3S), 104-115.

18. DHI. User's guide. 2011.

19. Thong, B.X.; Dan, N.V.; Trinh, N.M.; Ha, N.H. Using the method of soil conservation service curve number (SCS-CN) Combined with the Geographic information system (GIS) to estimate the surface runoff on the Co To Island, North Vietnam. Int. J. Adv. Eng. Res. Sci. 2019, 6(9), 59-75. https://dx.doi.org/10.22161/ijaers.69.6.

\title{
Application of Mike NAM and MIKE 11HD modeling tools to calculation $\mathrm{Cử}$ Long river basin surface water resources
}

\author{
Nguyen Ngoc Ha ${ }^{* *}$, Nguyen Manh Trinh ${ }^{1}$, Hoang Thi Nguyet Minh ${ }^{2}$ \\ ${ }^{1}$ National Center for Water Resource Planning and Investigation, Ministry of Natural \\ Resources and Environment, 93/95 Vu Xuan Thieu, Sai Dong, Long Bien, Ha Noi; \\ ha_tnn@yahoo.com; manhtrinh021@yahoo.com.vn \\ ${ }^{2}$ Hanoi University of Natural resources and Environment (HUNRE) , 41 Phu Dien, Bac Tu \\ Liem, Ha Noi; htnminh.tnn@hunre.edu.vn
}

\begin{abstract}
The Cuu Long river basin (CLRB) is the lower part of the Mekong basin located in Vietnam which consists of 13 provinces/cities in the South with great potential for economic development in agriculture, industry, fisheries, and ecotourism. Despite its dense river/canal system, the CLRB's water supply depends heavily on the amount of water from upstream. In order to serve the river basin management, planning, and sustainable development, it is highly important to assess the rainwater resources, surface water coming from upstream, and being in the CLRB. This study synthesized and analyzed documents related to surface water sources, combined with the use of MIKE-NAM, MIKE 11HD modeling tool to calculate and give a relatively clear picture of the characteristics and current status of rainwater and surface water in the CLRB. The results showed that for the whole CLRB, total rainwater resources is 68.4 billion $\mathrm{m}^{3}$, the surface water resources is 471 billion $\mathrm{m}^{3}$ of which, generated from rainfall is 30 billion $\mathrm{m}^{3}$, from upstream through the main river system and cross-transboundary spillage is 441 billion $\mathrm{m}^{3}$.
\end{abstract}

Keywords: Surface water resources; Cuu Long River basin; MIKE-NAM; MIKE 11 HD. 